This work has not been submitted for publication and thus has not undergone peer-review. The aim of this document is to report and make findings available from a pilot study funded by the VMSG Henry Emeleus Award.

\title{
Magma pathways in sill-complexes
}

\section{Dr Craig Magee', Dr Simon Martin², Dr William McCarthy³, Dr John MacDonald ${ }^{4}$}

\author{
${ }^{1}$ School of Earth and Environment, University of Leeds, Leeds, UK \\ ${ }^{2}$ School of Environmental Sciences, University of Liverpool, Liverpool, UK \\ ${ }^{3}$ School of Earth and Environmental Sciences, University of St Andrews, St Andrews, UK \\ ${ }^{4}$ School of Geographical and Earth Sciences, University of Glasgow, Glasgow, UK
}

This report documents the findings of a one-week fieldtrip, and associated lab analyses, to study the Loch Scridain Sill-complex (LSSC) on the Isle of Mull, Scotland. We gratefully acknowledge the support of the VMSG, who funded this work through the Henry Emeleus Award (2019). Magee designed the project and was aided in the field by Martin, who worked on the area as part of his $\mathrm{PhD}$, and MacDonald. Rock magnetic experiments and anisotropy of magnetic susceptibility analyses were conducted at the $\mathrm{M}^{3}$ Ore laboratory in the University of St Andrews. All raw data acquired during this work are archived at Figshare (link provided at report end) and freely available.

\section{Introduction}

With over 600 million people globally living near active volcanoes, understanding how volcano plumbing systems control eruption location, and style of precursor warning signals, is a fundamental issue facing volcanologists (e.g., Sparks et al. 2012; Cashman \& Sparks 2013; Cashman et al. 2017). The deeply eroded roots of ancient volcanoes preserved in the British and Irish Palaeogene Igneous Province (BIPIP) arguably birthed our understanding of subvolcanic plumbing systems (e.g., Bailey 1924; Richey \& Thomas 1930; Anderson 1936, 1937; Emeleus \& Bell 2005), and it is thus integral to constantly revisit this archetypal area and test new magma emplacement hypotheses. For example, classical models of ring dyke and cone sheet emplacement, developed through examination of BIPIP central complexes, have been revisited and tested (e.g., O'Driscoll et al. 2006; Stevenson et al. 2007; O'Driscoll et al. 2008; Stevenson \& Bennett 2011; Emeleus et al. 2012; Magee et al. 2012). Whilst interpretations of magmatic processes within the BIPIP broadly conform to a traditional view of plumbing systems, involving (sub-)vertical transport of magma between reservoirs and eruption sites (Fig. 1A) (e.g., Tibaldi 2015; Cashman et al. 2017), a consensus is now emerging that laterally injected intrusions (dykes or sills) can link adjacent volcanic systems (Fig. 1A) (e.g., Biggs et al. 2016; Magee et al. 2016b; Schofield et al. 2017). In particular, recent studies champion a new paradigm whereby magma flow through a network of sub-horizontal (sills) and inclined sheets (i.e. a sill-complex) can connect volcanoes across 1-1000's km (Fig. 1A) (e.g., Svensen et al. 2012; Magee et al. 2016b; Eide et al. 2017; Schofield et al. 2017), challenging our understanding of how volcanic systems work.

Sill-complexes cover areas up to $>1.5 \times 10^{6} \mathrm{~km}^{2}$, and comprise thin ( $<100 \mathrm{~m}$ thick) sills and inclined sheets injected over 0.5-15 Myrs (e.g., Chevallier \& Woodford 1999; Thomson \& Hutton 2004; Planke et al. 2005; Cartwright \& Hansen 2006; Leat 2008; Svensen et al. 2012; Coetzee \& Kisters 2016; Magee et al. 2016b; Schofield et al. 2017). Seismic reflection data reveal that flow pathways within sill-complexes can follow tortuous routes (e.g., Cartwright \& Hansen 2006; Magee et al. 2016b; Schofield et al. 2017). These convoluted pathways are expected to increase the time magma takes to reach the surface (Magee et al. 2016b). Conversely, because flow occurs through relatively thin intrusions, magma may be expected to solidify quickly (months to a few thousand years) (e.g., Holness \& Humphreys 2003; Annen 2011; Annen et al. 2015), certainly before such extensive sill-complexes can form (Magee et al. 2016b). A solution to this paradox is that sill-complexes form via incremental magma input, where solidified yet hot injections elevate the local temperature, allowing younger pulses to remain molten and flow for longer (e.g., 
Magee et al. 2016b). It has been hypothesised that these young injections of into sill-complexes are focused either: (i) in distinct channels in a sill (Fig. 1B); or (ii) along margins of earlier sills (i.e. accretion; Fig. 1C) (e.g., Annen et al. 2015; Magee et al. 2016b). These untested hypotheses imply only certain flow pathways are active at any one time. Therefore, although previous studies have examined the broad structure of sill-complexes and how individual intrusions inject (e.g., Hansen et al. 2004; Thomson \& Hutton 2004; Cartwright \& Hansen 2006; Thomson \& Schofield 2008; Schofield 2009; Schofield et al. 2012; Magee et al. 2014; Magee et al. 2016b; Schofield et al. 2017; Magee et al. 2019a), we do not know how entire sill-complexes are built or whether they actually allow connected volcanoes to dynamically interact.

The Loch Scridain Sill-complex on the Isle of Mull affords an opportunity to examine how magma moves through and builds sill-complexes (Holness \& Humphreys 2003). For example, field and petrological evidence indicates the Tràigh Bhàn na Sgùrra Sill is segmented and comprised several thick channels, separated by thin sill portions, that facilitated longer-lived magma flow (Holness \& Humphreys 2003; Stephens et al. 2017). We integrate structural field analysis and rock magnetic techniques in an attempt to identify and characterise magma flow pathways in the LSSC, with a view to expanding the study to understand how the entire sill-complex was constructed.
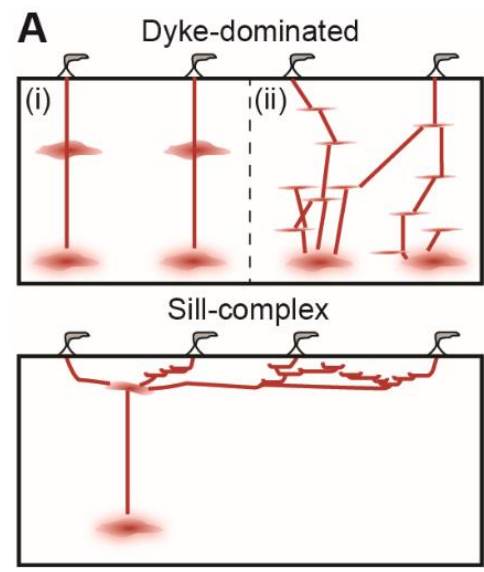

B

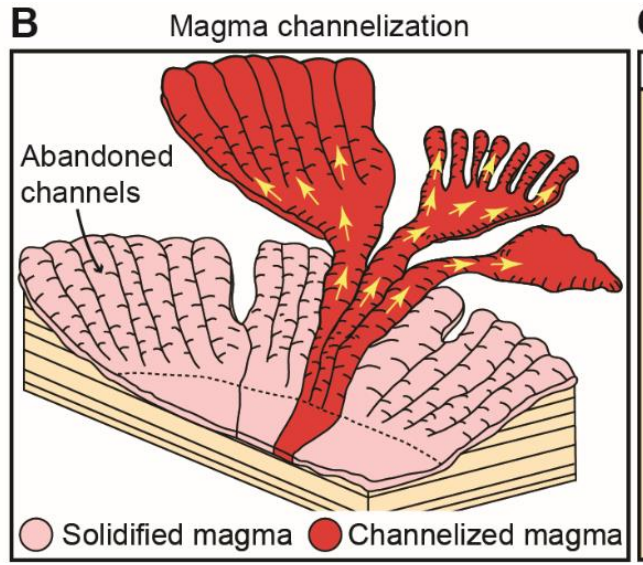

C

Sill accretion

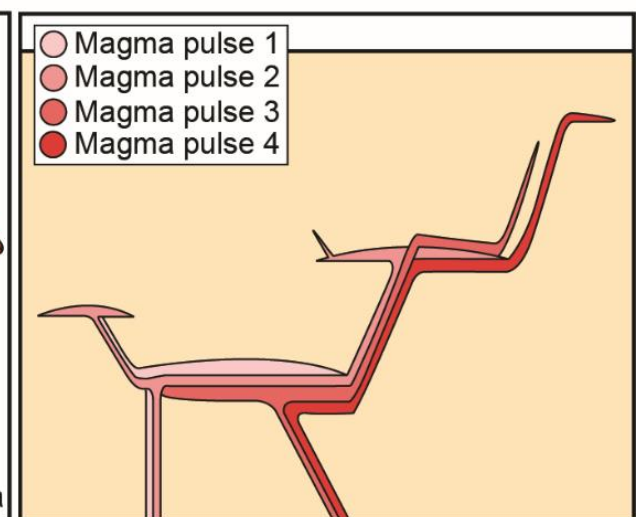

Figure 1: (A) Schematics depicting how magma plumbing systems are traditionally viewed as being 'vertically stacked', such that eruption sites broadly overlie zones of melt production, but that significant lateral magma transport in sill-complex (or dykes) may also occur. (B) Channelization of magma within finger-like structures may feed new sills (redrawn from Schofield 2009). (C) Heat from pre-existing sills may allow later, accreted sills to extend further (Magee et al. 2016b).

\section{Geological Setting}

Igneous rocks are widespread on the Isle of Mull, Scotland and primarily represent the plumbing system or eruptive products of magmatic activity related to the formation of the $\sim 62-55$ Myr old British and Irish Palaeogene Igneous Province (BIPIP), which forms part of the North Atlantic Igneous Province (Fig. 2A) (e.g., Bailey 1924; Emeleus \& Bell 2005). Sheet intrusions on Mull include regional dykes, cone sheets, and the LSSC. The 58 Ma LSSC is a wellexposed, mafic in composition, and relatively small $\left(\sim 100 \mathrm{~km}^{2}\right)$ sill-complex likely linked to the formation of the Mull Central Complex, which is considered the deeply eroded roots of an ancient volcanic edifice (Figs 2A and B) (Bailey 1924; Preston et al. 1998; Holness \& Humphreys 2003; Stephens et al. 2017). Palaeostress analysis particularly reveal the LSSC was emplaced during horizontal radial compression induced by central complex formation (Stephens et al. 2017). Here, we focus on the Tràigh Bhàn na Sgùrra Sill, which is located along the SW coast of Mull where it is intruded into steeply to vertically dipping, metasedimentary psammites and pelites of the Precambrian Moine basement (Figs 2B and C) (Holness \& Humphreys 2003; Stephens et al. 2017). The petrology and chemistry of the Tràigh Bhàn na Sgùrra Sill has been well characterised and comprises olivine-poor and olivine-free dolerite, which commonly hosts Fe-Ti oxides (see Holness \& Humphreys 2003 and references therein). Critically, sections where sill 
thickness exceeds $\sim 3.5 \mathrm{~m}$ have no chilled margin and a wide contact aureole, in contrast to thinner sections, suggesting magma was channelized into these thick zones (Fig. 2C); modelling of these observations is consistent with sustained magma flow within thicker sections of the sill for 5-6 months, with the thinner sections crystallising in days (Kille et al. 1986; Wartho et al. 2001; Holness \& Humphreys 2003). Lineations are also visible throughout the sill at various structural levels and have been interpreted to reflect magma flow (Fig. 2C) (Holness \& Humphreys 2003). Other possible field flow indicators include steps (Stephens et al. 2017), which are connectors between two subhorizontal sill elements.

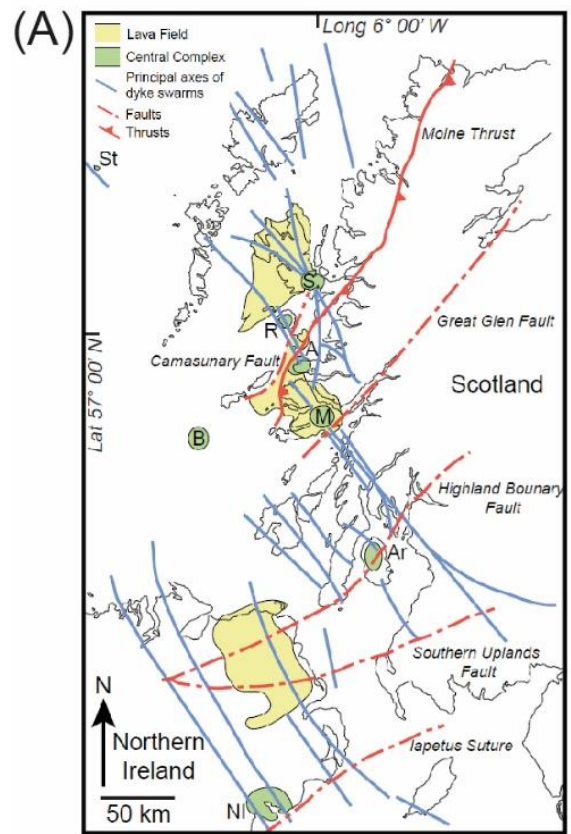

(B)

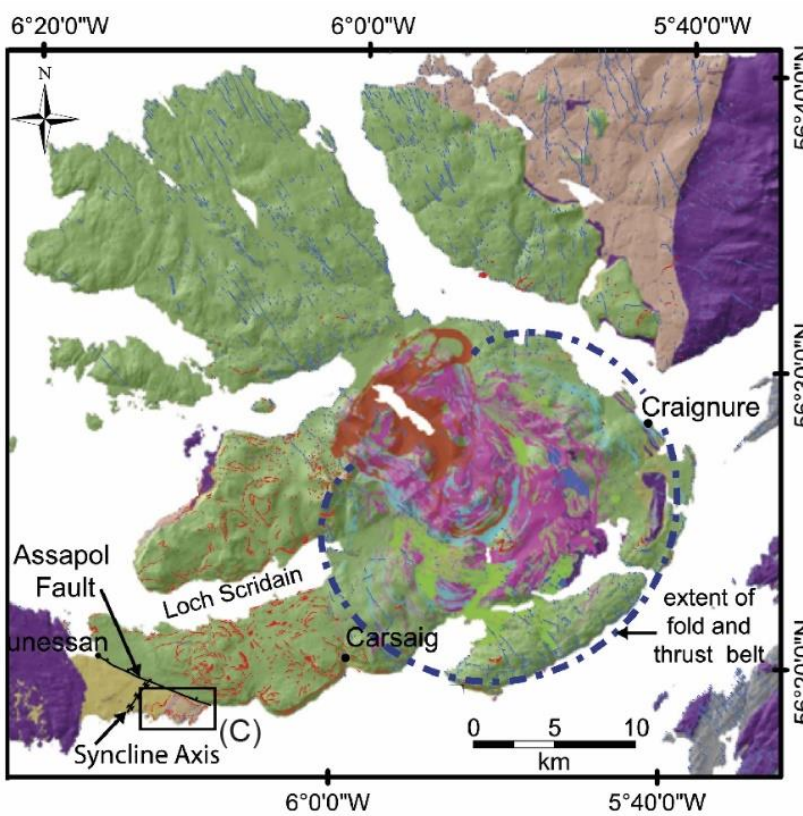

Paleogene Intrusives

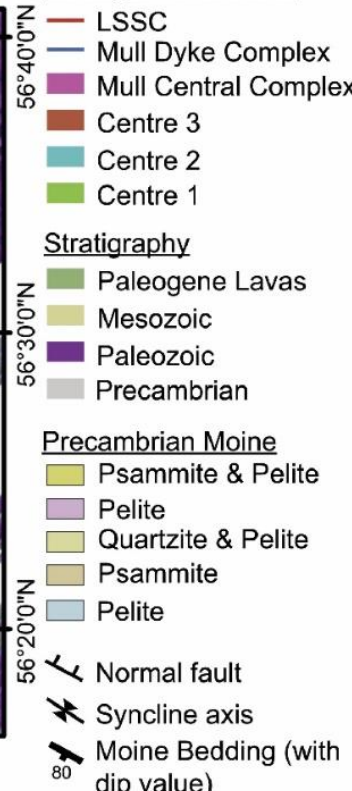

Moine Bed
dip value)

(C)

$6^{\circ} 10^{\prime} 0^{\prime \prime} \mathrm{W}$

$6^{\circ} 8^{\prime} 0^{\prime \prime} \mathrm{W}$

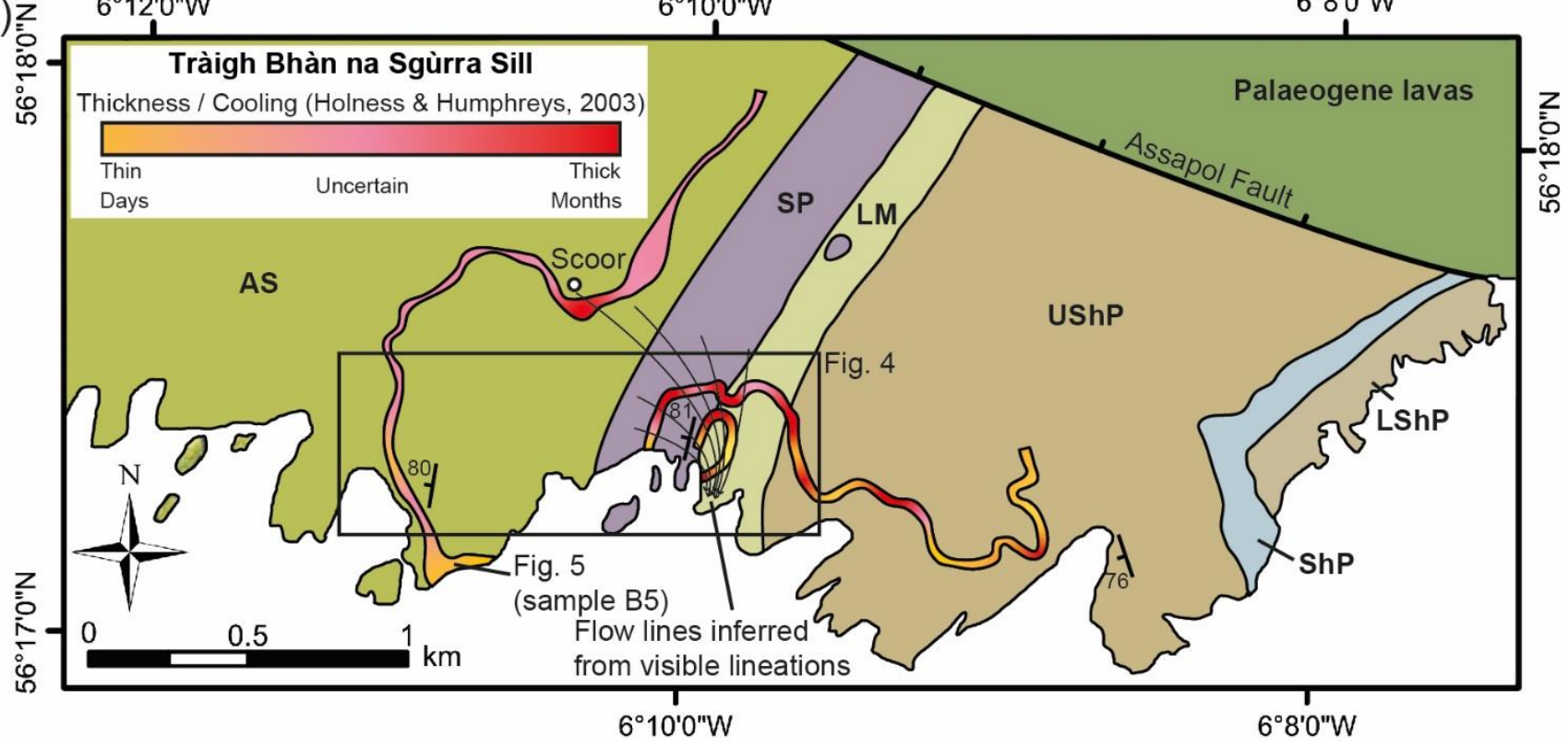

Figure 2: $(\mathrm{A})$ Map of the distribution of flood basalt lavas, NW-SE regional dykes and central complexes in the British and Irish Palaeogene Igneous Province (BIPIP) (redrawn from Emeleus \& Bell 2005). The central complexes are: St St Kilda; S - Skye; R - Rum; A - Ardnamurchan; M - Mull; B - Blackstones; Ar - Arran; NI - Northern Ireland central complexes including Slieve Gullion, Carlingford and the Mournes. Major Caledonian faults are also displayed. (B) Simplified geological map Mull (DiGMapGB-50 a) of Mull (Stephens et al. 2017). See (A) for location. (C) Geological map of the Tràigh Bhàn na Sgùrra Sill and its host rocks (redrawn from Stephens et al. 2017); other sheet intrusions omitted for clarity. Areas where the Tràigh Bhàn na Sgùrra Sill are thick and magma flow was channelized over 5-6 months are shown compared to areas where the sill is thin and cooled quickly (over days) or its thickness uncertain 
(after Holness \& Humphreys 2003). LShP - Lower Shiaba Psammite Formation; ShP - Shiaba Pelite Formation; UShP - Upper Shiaba Psammite Formation; LM - Lagan Mor Formation; SP - Scoor Pelite Formation; AS - Ardalanish Striped Formation. See (B) for location.

\section{Methods}

As magma intrudes, it cools and begins to crystallise; injected magma may also carry a crystal cargo extracted from a previous storage site. The arrangement, size, shape, and orientation of these crystals, i.e. the rock texture, record kinetic (e.g., magma flow fabrics) and equilibration processes (e.g., Holness \& Humphreys 2003; Higgins 2006; Magee et al. 2013). It may therefore be expected that accretion and channelization, where parts of the sill-complex remain hotter for longer, produce a distinct textural record that can be evaluated via integrated rock fabric analyses. Numerous studies have demonstrated that magnetic fabrics measured by Anisotropy of Magnetic Susceptibility (AMS), particularly those reflecting the shape and orientation of ferromagnetic minerals (e.g., magnetite), can provide a record of primary magma flow in igneous sheet intrusions (e.g., Knight \& Walker 1988; Ferré et al. 2002; CanonTapia 2004; Féménias et al. 2004; Philpotts \& Philpotts 2007; Aubourg et al. 2008; Magee et al. 2012; Magee et al. 2013; Magee et al. 2016a). For example, measurement of magnetic fabric imbrication adjacent to sheet margins, where magma flow was slower, can be used to infer magma flow direction (e.g., Knight \& Walker 1988; Tauxe et al. 1998; Callot et al. 2001; Aubourg et al. 2008; Magee et al. 2013; Magee et al. 2016a; Martin et al. 2019).

Of the 17 total block samples collected (B1-B18; there is no B11), most were acquired from vertically oriented transects across the sill, targeting areas where the sill is thin and thick (Holness \& Humphreys 2003), whereby a sample was taken from the top, middle, and base of the intrusion (one transect only has samples from the top and base). The rationale for this sampling strategy was to analyse whether magnetic fabrics differed across the intrusion and along its strike, particularly between areas where magma flow within the sill was longer-lived (thick sections) and those where it was limited (thin sections) (Holness \& Humphreys 2003). We also collected one sample from a step connector between two segments (B1), and one from an area where lineations at multiple levels within the sill are visible in the field (B5); the aim of these was to test whether the connector or lineation long axes aligned with the magnetic fabric. Here, we use anisotropy of magnetic susceptibility (AMS) to measure magnetic fabrics from 12 oriented block samples collected from the Tràigh Bhàn na Sgùrra Sill of the LSSC; a further five samples were collected but their analysis was delayed by the Covid-19 pandemic - data for these will be added once acquired. Right cylinder sub-specimen drill core samples measuring $22 \mathrm{~mm}$ by $25 \mathrm{~mm}$ were extracted from each block sample using a rock coring drill press and a diamond-tipped, non-magnetic saw blade. Each sub-specimen was analysed using an automated 3D rotator attached to a KLY-5a Kappabridge operating at a low alternating field of $400 \mathrm{~A} / \mathrm{m}$ at $1220 \mathrm{HZ}$ at the University of St. Andrews M²Ore Laboratory, and the results averaged for each block using Agico Anisoft 42 software.

AMS analyses measure the bulk magnetic susceptibility of an individual sub-specimen along multiple axes to derive its $3 D$ susceptibility tensor, which is defined by three principal axes $\left(K_{1} \geq K_{2} \geq K_{3}\right)$. The maximum axis $\left(K_{1}\right)$ is usually characterised as the magnetic lineation and thought to parallel the crystallographic long axes of the minerals carrying the magnetic signature, with the short axis $\left(\mathrm{K}_{3}\right)$ being the pole to the magnetic foliation plane (i.e. the $\mathrm{K}_{1}-\mathrm{K}_{2}$ plane) (e.g., Tarling \& Hrouda 1993); these classifications are only viable if the fabric is 'normal', and not related to phases that produce 'intermediate' or 'inverse' fabrics where the principal magnetic axes no longer simply correspond to crystallographic axes (e.g., Ferré 2002). The three principal axis directions and sub-specimen data for each block sample are plotted stereographically with $95 \%$ confidence limits; we also plot $\mathrm{K}_{1}, \mathrm{~K}_{2}$, and $\mathrm{K}_{3}$ on a separate stereonets where we display the magnetic foliation, adjacent contact orientations, and possible visible field flow indicator axes if present. In addition to constraining fabric orientation, AMS also measures the mean magnetic susceptibility $\left(\mathrm{K}_{\mathrm{m}}\right)$, Shape Factor $\left(\mathrm{T}_{\mathrm{j}}\right)$, and Degree of Anisotropy (or strength of ellipticity; $\mathrm{P}_{\mathrm{j}}$ ) of the ellipsoid: 
$\mathrm{K}_{\mathrm{m}}=\left(\mathrm{K}_{1}+\mathrm{K}_{2}+\mathrm{K}_{3}\right) / 3$

$P_{j}=\exp \sqrt{ }\left(2\left[\left(\eta_{1}-\eta_{m}\right)^{2}+\left(\eta_{2}-\eta_{m}\right)^{2}+\left(\eta_{3}-\eta_{m}\right)^{2}\right]\right.$

$T_{j}=\left(2 \eta_{2}-\eta_{1}-\eta_{3}\right) /\left(\eta_{1}-\eta_{3}\right)$

where,

$\eta_{x}=\ln \left(K_{x}\right), x=1,2,3$, and $\eta_{m}=\left(\eta_{1}+\eta_{2}+\eta_{3}\right) / 3$

Ellipsoid shape ranges from oblate $\left(T_{j}=+1\right)$ to prolate $\left(T_{j}=-1\right)$.

\section{Rock magnetic experiments}

As exemplified by the recognition that magnetic fabrics may be normal, intermediate, or inverse, the interpretation of AMS requires knowledge of the mineralogy controlling its signature. The interpretation of AMS data is subject to several caveats. We conducted thermomagnetic experiments on one sample (i.e. B1) to provide insight into the composition, grain size, and domain state of the mineral phase(s) controlling the AMS response (e.g., Dunlop \& Özdemir 2001). These experiments involve powdering a sub-specimen in a ceramic pestle and mortar to acquire a 0.3 $\mathrm{g}$ powder sub-sample. The powder was cooled in liquid nitrogen and magnetic susceptibility was measured as the sample heated from $-194^{\circ} \mathrm{C}$ to $0^{\circ} \mathrm{C}$ using a KLY5 CS-L cryostat. The sample was placed in a KLY5 CS4 furnace and, in an argon atmosphere, magnetic susceptibility was measured from $25^{\circ} \mathrm{C}$ to $700^{\circ} \mathrm{C}$ and back to $40^{\circ} \mathrm{C}$. Finally, the susceptibility was again measured from $-194^{\circ} \mathrm{C}$ to $0^{\circ} \mathrm{C}$ in the KLY5 CS-L. The results were reduced in Cureval 8 software where a continuous temperature vs susceptibility plot was generated. From our thermomagnetic experiment we estimated the Curie point using the inflection point method (Tauxe et al., 1998); this transition can be used to interpret the magnetic mineralogy of each sample and determine what mineral phases control the AMS response (e.g., Dunlop \& Özdemir 2001).

\section{Preliminary Results and Interpretation}

\section{Rock magnetic experiments}

The heating curve shows a steady increase in susceptibility from room temperature to $320^{\circ} \mathrm{C}$ where a sharp decrease in susceptibility occurs (Fig. 3); this profile is characteristic of titanomagnetite and the absense of an abrupt hopkinsons peak is consistent with the dominance of multidomain-to-pseudosingle domaign ferromagnetic grains. From its Curie temperature we determine that the Ti component of the $\mathrm{Fe}^{2+}\left(\mathrm{Fe}^{3+}, \mathrm{Ti}_{2}\right)_{4} \mathrm{O}_{4}$ titanomagneite is $\sim 0.41$ (Akimoto 1962). The heating and cooling curves are not reversable and we note that the Curie point shown on the cooling curve occurs at a much lower temperture than the heating curve, yet the measured starting and final bulk suscetpability values are very closely comparable (Fig. 3). These differences in the heating and cooling curve profiles indicates that a mineralogical change occurred during the experiment and that this change did not produce or destroy substantial volumes of magnetite; we interpret these results to show the resorption of titanium into titanomagnetite. 


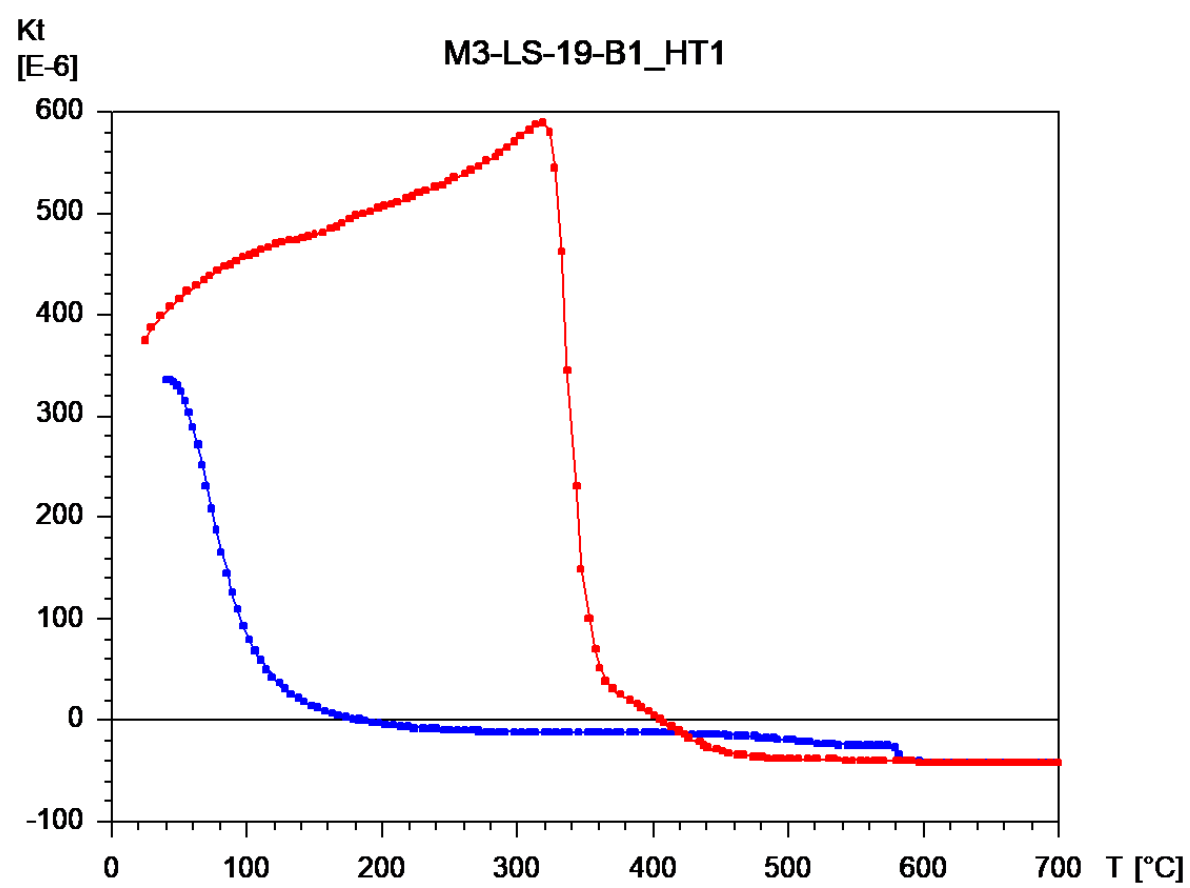

Figure 3: Temperature vs susceptibility variations during heating (red) and cooling (blue) of sample B1.

\section{Anisotropy of magnetic susceptibility - test of magma channelization Observations}

Here we present data for vertical sampling transects across a headland exposure of the Tràigh Bhàn na Sgùrra Sill, which currently includes samples B2-B4, B8-B10, B12, B14, and B17-B18; once analysed we will add the remaining samples. The AMS sub-specimen data for each block sample are consistent, producing small and well-defined

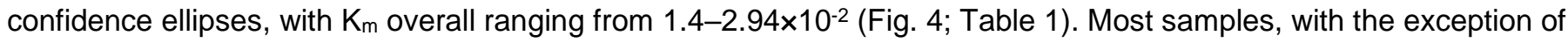
B2 ( $T=0.53$; oblate), contain triaxial-to-prolate magnetic farbics ( $T=-0.002--0.735)$ (Fig. 4; Table 1). The only full transect currently available is samples B2-B4, where the sills is $\sim 2 \mathrm{~m}$ thick, which all show south-easterly (143.5$155.9^{\circ}$ ) trending $\mathrm{K}_{1}$ axes that increase in plunge from $5.7^{\circ}$ at the top of the sill to $20.2^{\circ}$ (middle) and $29.7^{\circ}$ at the base (Fig.4; Table 1). Conversely, for B2-B4, the magnetic foliation dip decreases from $67.8^{\circ}$ at the top of the sill to $45.8^{\circ}$ (middle) and $38.1^{\circ}$ at the base; magnetic foliation strike changes from $158.3^{\circ}$ at the top of the sill to $164.5^{\circ}$ (middle) and $011.6^{\circ}$ at the base (Fig. 4 ; Table 1). The contact orientation at the top of the sill near B2 $\left(158 / 68^{\circ} \mathrm{SE}=\right.$ magnetic foliation) is, on average, $035 / 17^{\circ} \mathrm{SE}$, whereas the contact orientation at the top of the sill near $\mathrm{B} 2\left(012 / 38^{\circ} \mathrm{SE}=\right.$ magnetic foliation) is, on average, $056 / 20^{\circ} \mathrm{SE}$ (Fig. 4; Table 1). For both $\mathrm{B} 2$ and $\mathrm{B} 4, \mathrm{~K}_{1}$ is located close to the plane of the intrusion (defined by contact orientations) (Fig. 4). The intersection between the magnetic foliations of B2 and B4 coincides with the $B 4 K_{1}$ axis (Fig. 4). For other samples from vertical transects there is a variable relationship between the orientation of $K_{1}$ and the magnetic foliation relative to the adjacent sill contact (Fig. 4). For example, the magnetic foliations of B12 and B17 broadly strike parallel to the sill contacts and, although they dip SE instead of NW, they dip ate similar values (Fig. 4; Table 1). Conversely, for samples B9 and B18, the magnetic foliation is near orthogonal to the sill strike and dip (Fig. 4; Table 1). In no sample does $\mathrm{K}$. closely parallel features identified in the field as possible magma flow indicators (Fig. 4). 


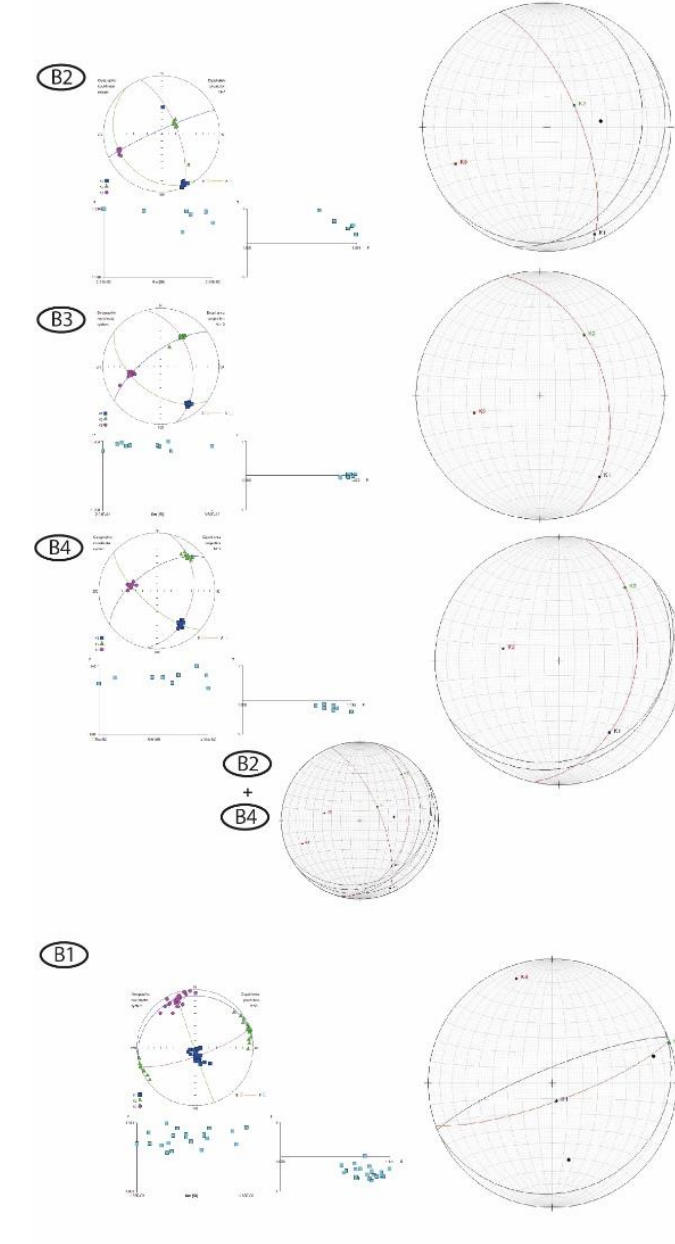

(B)
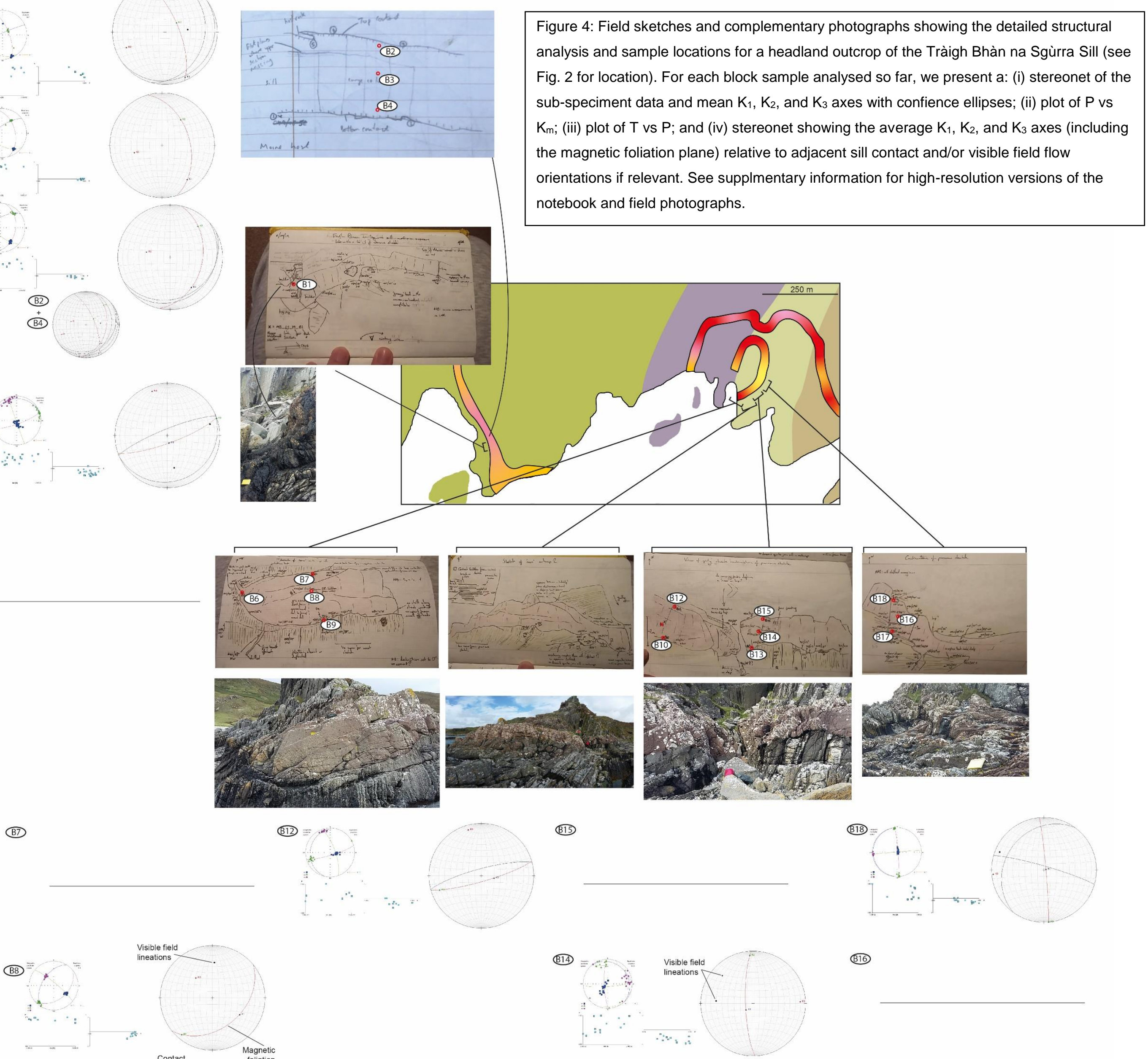

(19) $=-\infty=\quad$ Contact
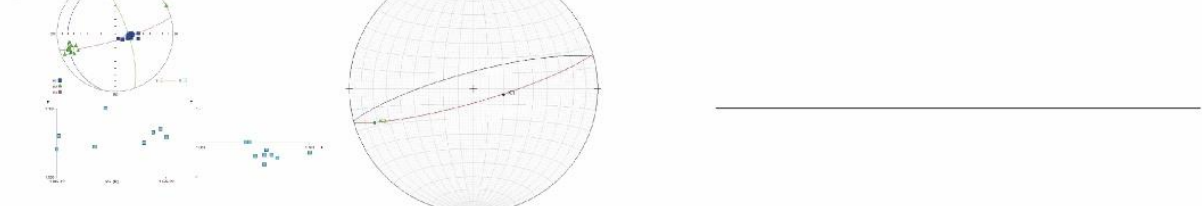

(6)

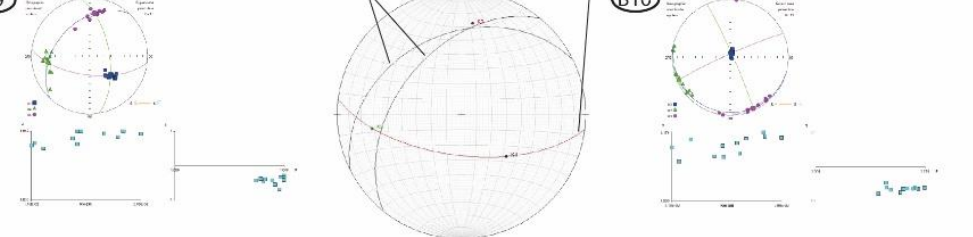

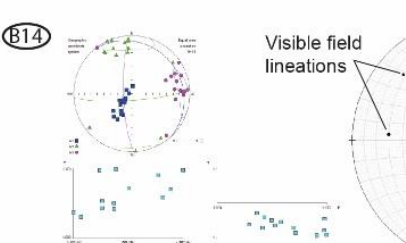

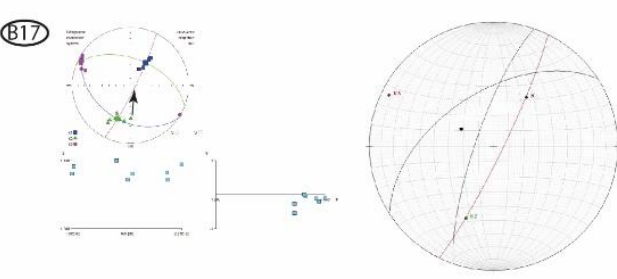


Interpretation

The $\mathrm{K}_{\mathrm{m}}$ range of $1.4-2.94 \mathrm{E} \times 10^{-2}$ is consistent with the thermomagnetic experiments results that indicate multidomain titanomagnetite-to-pseudosingle is the principal contributor to the magnetic signature of the samples (Fig. 3). However, we note that some magnetic fabrics (e.g., B9 and B18) are near-orthogonal to the plane of intrusion, which may suggest that these few fabrics are inverse and could be dominated by a single-domain magnetite population (e.g., Ferré 2002); i.e. for normal magnetic fabrics, $\mathrm{K}_{1}$ and $\mathrm{K}_{2}$ are expected to be within or near the plane of intrusion.With most samples displaying triaxial-to-prolate fabrics, interpretation of magnetic foliations has to be considered carefully; critically we note that although prolate fabrics occur because the magnitude of $K_{2}$ and $K_{3}$ are similar, the well-defined confidence ellipses we derive suggest that we can constrain $K_{2}$ and thus use the $K_{1}-K_{2}$ plane as the magetic foliation (Fig. 4). Importantly, we show magnetic fabric orientations are variable (Fig. 4), suggesting fabrics within the sill have not been overprinted by syn- or post-emplacement deformation. Based on the variation in fabric orientation and the evidence the magnetic signature is carried by titanomagnetite, with little influence from other phases, we suggest the magnetic fabrics likely have a magmatic origin.

We currently lack the full set of samples to determine whether flow patterns were different between thicker, and perhaps longer-lived (Holness \& Humphreys 2003), portions of the sill and other sections. If we consider the magnetic foliations of B2 and B4, which sample the sill margin adjacent to the host rock contact, are normal (Ferré 2002) and define a flow-related imbrication our results would imply magma, at least locally, towards the NW (see Geoffroy et al. 2002). Whether we can relate $K_{1}$ to the magma flow direction (e.g., Knight \& Walker 1988; Callot et al. 2001; Magee et al. 2012) is difficult to determine yet due to its different plung relative to that of visible field flow indicators (e.g., assumed flow lineations and step axes) (Fig. 4). This difference between the field flow indicator orientations and magnetic farbics could be because: (i) they each record separate stages of magma emplacement; (ii) the block samples where collected in an area where magma flow was different (i.e. magma flow may have been heterogeneous over short distances; Magee et al. 2013; Magee et al. 2016a); or (iii) one or both do not record magma flow, but instead reflect other processes.

\section{Anisotropy of magnetic susceptibility - test of visible field flow indicators}

\section{Observations}

Here we test further whether the magnetic lineations relate to possible indicators of magma flow observed in the field. Specifically, we collected sample B1 from the junction between two sill elements, which has a step-like geometry (Fig. 4), and B5 from a surface displaying promient lineations (Fig. 5). For B1, which has a prolate fabric ( $\mathrm{T}=-0.48)$ and a $\mathrm{K}_{\mathrm{m}}$ of $2.5 \mathrm{E}-02, \mathrm{~K}_{1}$ plunges $78 / 167^{\circ}$ whereas the step long axis is $17 / 075^{\circ}$; a set of potential lineations near $\mathrm{B} 1$ trends $37 / 168^{\circ}$ (Fig. 4; Table 1). The strike of the $\mathrm{B} 1$ magnetic foliation $\left(070^{\circ}\right)$ I sub-parallel to the upper sill sub-horizontal contact $\left(065^{\circ}\right)$ and the sub-vertical step wall $\left(068^{\circ}\right)$ (Fig. 4; Table 1). For B5, which has a triaxial-to-oblate fabric $(\mathrm{T}=$ 0.218 ) and a $\mathrm{K}_{\mathrm{m}}$ of $3.46 \mathrm{E}-02$, $\mathrm{K}_{1}$ plunges $67 / 150^{\circ}$ whereas the observed lineations trend $01 / 340^{\circ}$ (Fig. 5 ; Table 1). 

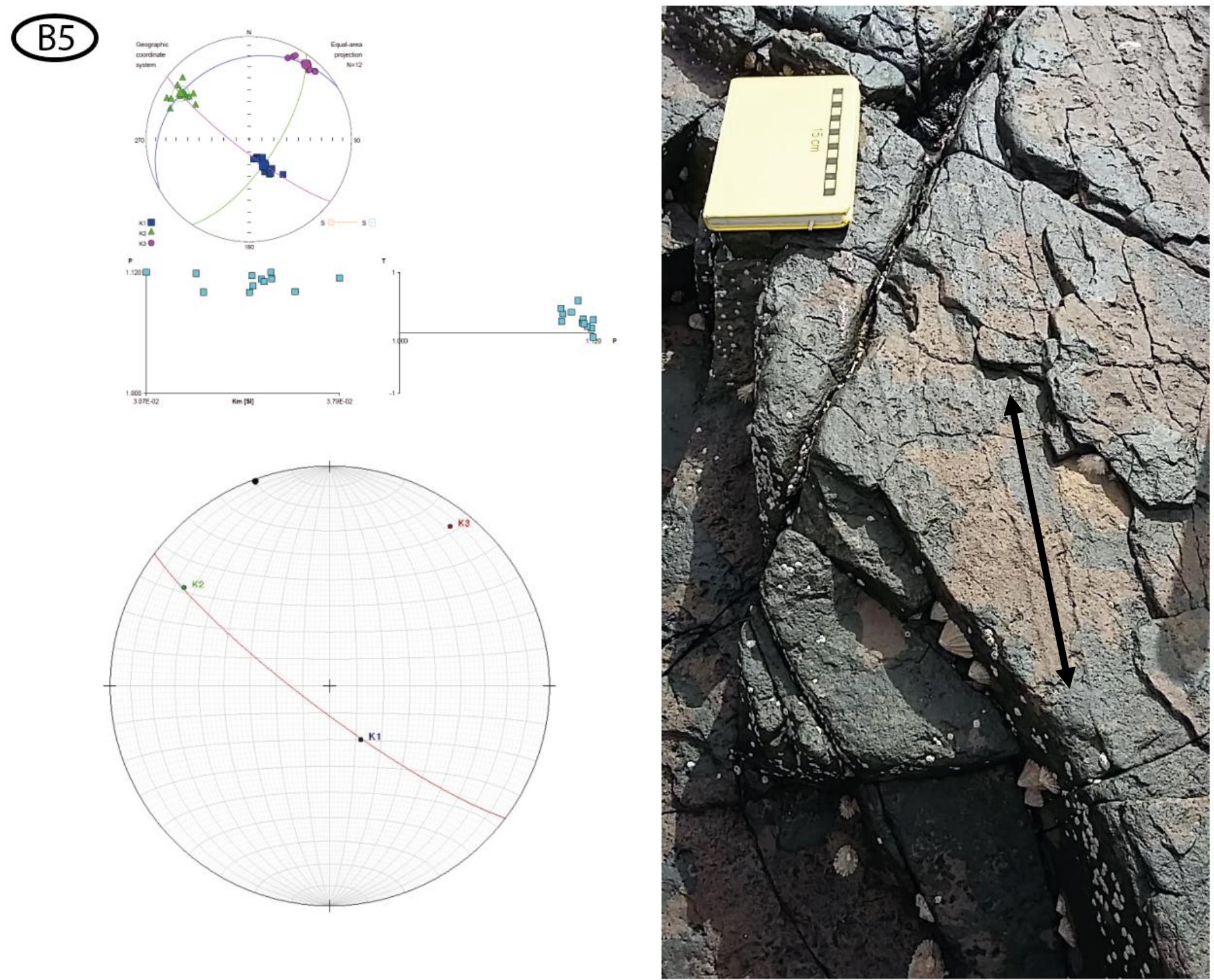

Figure 5: AMS data for sample B5, which was collected to establish whether the lineations (black circle on the lower leftstereonet; black arrow on the outcrop photo) observed on its surface related to the magnetic fabric. See Figure $2 \mathrm{C}$ for location.

\section{Interpretation}

Sheet intrusions such as sills commonly emplace as discrete elements that through continued magma flow and element infaltion, coalesce to form a throughgoing sheet (Fig. 6) (see Magee et al. 2019b and references therein). These element typically occur at slightly differnet stratigraphic and/or structural levels, such that when they coalesce, they connect via the formation of a step or briken bridge connector (Fig. 6) (Magee et al. 2019b; Köpping et al. 2021). Critically, the long axes of these connectors is parallel to the sheet propagation axis (Fig. 6) (Magee et al. 2019b; Köpping et al. 2021). The parallelism between the sample B1 $\mathrm{K}_{1}$ trend and that of the intrusive step it is associated with suggest the former may be considered a proxy for the sheet emplacement axis (Fig. 4). 

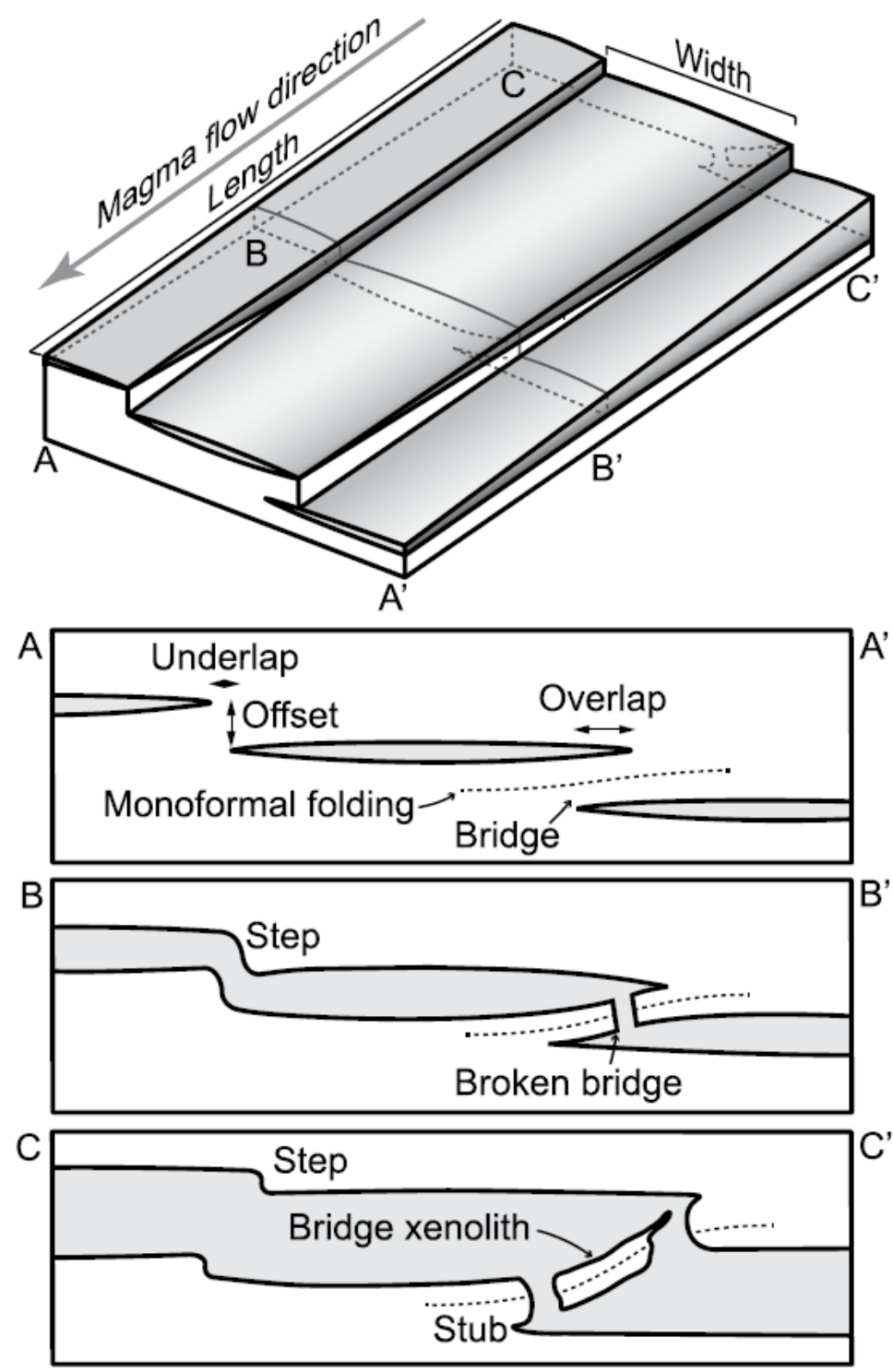

Figure 6: Schematic diagram documenting the description and development of segments connected by steps and bridge structures (Magee et al. 2019b).

Lineations observed along surfaces exposed within and throughout (i.e. not just at the host rock contact) the Tràigh Bhàn na Sgùrra Sill have previously been inferred to record magma flow axes (Holness \& Humphreys 2003). Our work, particularly the disparity we show between the magnetic fabric and the lineations of sample B5, questions whether this inferred link between the visible lineations and magma flow is valid.

\section{Concluding Remarks and Future Work}

The aim of this study was to test whether there is a systematic variation in the magnetic fabric across the the Tràigh Bhàn na Sgùrra Sill relative to areas where the sill was short- and long-lived. Although we have not been able to analyse all samples yet, our results currently are sufficient to indicate: (i) fabrics do vary, implying they are not related to a tectonic overprint; (ii) deciphering the magnetic mineralogy will be key to understanding why fabrics may vary, particulalrly those magnetic lineations and foliations oriented near-orthogonal to the sill plane; and (iii) there is rarely a clear relationship between magnetic lineation and features observed in outcrop that may be interpreted as mimicking the magma flow axis (i.e. flow lineations and steps). Future work within the scope of our study required to improve our understanding of magma flow patterns and channelization in the Tràigh Bhàn na Sgùrra Sill include: (i) finish analysing the AMS of collected blocks, which will allow us to identify any imbrication of magnetic fabrics from which magma flow direction can be inferred; (ii) conduct further rock magnetic experiments to better characterise the magnetic mineralogy of the sill (e.g., more thermomagnetic experiments, Lowrie-Fuller test); (iii) analysing a few 
samples for anisotropy of anhysteretic remanent magnetisation, which can help identify whether AMS fabrics are the product of sub-fabric averaging; and (iv) petrological studies to determine how the magnetic fabric relates to the orientation of silicate phases and whether textural variations (e.g., crystal size distribution, equilibration) vary across the sill.

\section{Acknowledgements}

We are grateful to the VMSG for funding this work through their Henry Emeleus Award, and we hope this contribution helps build Henry's legacy as a pioneer of understanding magma plumbing systems.

\section{Data Availability}

All data used in this report are published and freely available at

https://figshare.com/articles/dataset/Loch Scridain Sill-Complex data - Henry Emeleus Award 2019/14184860.

\section{References}

Akimoto, S. 1962. Magnetic properties of FeO-Fe2O3-TiO2 system as a basis of rock magnetism. Journal of the Physical Society of Japan, 17, 706-\&.

Anderson, E.M. 1936. Dynamics of formation of cone-sheets, ring-dykes, and cauldron subsidence. Proceedings of the Royal Society of Edinburgh, 56, 29.

Anderson, E.M. 1937. Cone-sheets and ring-dykes: the dynamical explanation. Bulletin Volcanologique, 1, 35-40, http://doi.org/10.1007/BF03028041.

Annen, C. 2011. Implications of incremental emplacement of magma bodies for magma differentiation, thermal aureole dimensions and plutonism-volcanism relationships. Tectonophysics, 500, 3-10.

Annen, C., Blundy, J.D., Leuthold, J. \& Sparks, R.S.J. 2015. Construction and evolution of igneous bodies: Towards an integrated perspective of crustal magmatism. Lithos, 230, 206-221, http://doi.org/http://dx.doi.org/10.1016/j.lithos.2015.05.008.

Aubourg, C., Tshoso, G., Le Gall, B., Bertrand, H., Tiercelin, J.J., Kampunzu, A.B., Dyment, J. \& Modisi, M. 2008. Magma flow revealed by magnetic fabric in the Okavango giant dyke swarm, Karoo igneous province, northern Botswana. Journal of Volcanology and Geothermal Research, 170, 247-261, http://doi.org/http://dx.doi.org/10.1016/i.jvolgeores.2007.10.013.

Bailey, E.B. 1924. Tertiary and Post-Tertiary Geology of Mull, Loch Aline, and Oban: A Description of Parts of Sheets 43, 44, 51, and 52 of the Geological Map. HM Stationery Office.

Biggs, J., Robertson, E. \& Cashman, K. 2016. The lateral extent of volcanic interactions during unrest and eruption. Nature Geoscience, 9, 308-311.

Callot, J.-P., Geoffroy, L., Aubourg, C., Pozzi, J. \& Mege, D. 2001. Magma flow directions of shallow dykes from the East Greenland volcanic margin inferred from magnetic fabric studies. Tectonophysics, 335, 313-329. 
Canon-Tapia, E. 2004. Anisotropy of magnetic susceptibility of lava flows and dykes: A historical account. Geological Society, London, Special Publications, 238, 205-225, http://doi.org/10.1144/gsl.sp.2004.238.01.14.

Cartwright, J. \& Hansen, D.M. 2006. Magma transport through the crust via interconnected sill complexes. Geology, 34, 929-932, http://doi.org/10.1130/g22758a.1.

Cashman, K.V. \& Sparks, R.S.J. 2013. How volcanoes work: A 25 year perspective. Geological Society of America Bulletin, 125, 664-690.

Cashman, K.V., Sparks, R.S.J. \& Blundy, J.D. 2017. Vertically extensive and unstable magmatic systems: A unified view of igneous processes. Science, 355, eaag3055, http://doi.org/10.1126/science.aag3055.

Chevallier, L. \& Woodford, A. 1999. Morpho-tectonics and mechanism of emplacement of the dolerite rings and sills of the western Karoo, South Africa. South African Journal of Geology, 102, 43-54.

Coetzee, A. \& Kisters, A. 2016. The 3D geometry of regional-scale dolerite saucer complexes and their feeders in the Secunda Complex, Karoo Basin. Journal of Volcanology and Geothermal Research, 317, 66-79.

Dunlop, D.J. \& Özdemir, Ö. 2001. Rock magnetism: fundamentals and frontiers. Cambridge University Press.

Eide, C.H., Schofield, N., Jerram, D.A. \& Howell, J.A. 2017. Basin-scale architecture of deeply emplaced sill complexes: Jameson Land, East Greenland. Journal of the Geological Society, 174, 23-40.

Emeleus, C.H. \& Bell, B. 2005. The Palaeogene volcanic districts of Scotland. British Geological Survey.

Emeleus, C.H., Troll, V.R., Chew, D.M. \& Meade, F.C. 2012. Lateral versus vertical emplacement in shallow-level intrusions? The Slieve Gullion Ring-complex revisited. Journal of the Geological Society, 169, 157-171, http://doi.org/10.1144/0016-76492011-044.

Féménias, O., Diot, H., Berza, T., Gauffriau, A. \& Demaiffe, D. 2004. Asymmetrical to symmetrical magnetic fabric of dikes: Paleo-flow orientations and Paleo-stresses recorded on feeder-bodies from the Motru Dike Swarm (Romania). Journal of Structural Geology, 26, 1401-1418, http://doi.org/10.1016/i.jsg.2003.12.003.

Ferré, E.C. 2002. Theoretical models of intermediate and inverse AMS fabrics. Geophysical Research Letters, 29, 3131-31-34.

Ferré, E.C., Bordarier, C. \& Marsh, J.S. 2002. Magma flow inferred from AMS fabrics in a layered mafic sill, Insizwa, South Africa. Tectonophysics, 354, 1-23.

Geoffroy, L., Callot, J., Aubourg, C. \& Moreira, M. 2002. Magnetic and plagioclase linear fabric discrepancy in dykes: a new way to define the flow vector using magnetic foliation. Terra Nova, 14, 183-190.

Hansen, D.M., Cartwright, J.A. \& Thomas, D. 2004. 3D seismic analysis of the geometry of igneous sills and sill junction relationships. In: Davies, R.J., Cartwright, J., Stewart, S.A., Lappin, M. \& Underhill, J.R. (eds) 3D seismic technology: Application to the Exploration of Sedimentary Basins. Geological Society, London, Special Publications, 29, 199-208. 
Higgins, M.D. 2006. Quantitative textural measurements in igneous and metamorphic petrology. Cambridge University Press Cambridge.

Holness, M. \& Humphreys, M. 2003. The Traigh Bhàn na Sgùrra sill, Isle of Mull: Flow localization in a major magma conduit. Journal of Petrology, 44, 1961-1976.

Kille, I., Thompson, R., Morrison, M. \& Thompson, R. 1986. Field evidence for turbulence during flow of basalt magma through conduits from southwest Mull. Geological Magazine, 123, 693-697.

Knight, M.D. \& Walker, G.P. 1988. Magma flow directions in dikes of the Koolau Complex, Oahu, determined from magnetic fabric studies. Journal of Geophysical Research, 93, 4301-4319.

Köpping, J., Magee, C., Cruden, A.R., Jackson, C.A.-L. \& Norcliffe, J. 2021. The building blocks of igneous sheet intrusions: insights from 3D seismic reflection data. EarthArXiv.

Leat, P.T. 2008. On the long-distance transport of Ferrar magmas. Geological Society, London, Special Publications, 302, 45-61, http://doi.org/10.1144/sp302.4.

Magee, C., Jackson, C.L. \& Schofield, N. 2014. Diachronous sub-volcanic intrusion along deep-water margins: insights from the Irish Rockall Basin. Basin Research, 26, 85-105.

Magee, C., O'Driscoll, B., Petronis, M. \& Stevenson, C. 2016a. Three-dimensional magma flow dynamics within subvolcanic sheet intrusions. Geosphere, GES01270. 01271.

Magee, C., Stevenson, C., O'Driscoll, B., Schofield, N. \& McDermott, K. 2012. An alternative emplacement model for the classic Ardnamurchan cone sheet swarm, NW Scotland, involving lateral magma supply via regional dykes. Journal of Structural Geology, 43, 73-91, http://doi.org/http://dx.doi.org/10.1016/i.jsg.2012.08.004.

Magee, C., Ernst, R.E., Muirhead, J., Phillips, T. \& Jackson, C.A.-L. 2019a. Magma Transport Pathways in Large Igneous Provinces: Lessons from Combining Field Observations and Seismic Reflection Data. In: Srivastava, R., Ernst, R. \& Peng, P. (eds) Dyke Swarms of the World: A Modern Perspective. Springer, 45-85.

Magee, C., O’Driscoll, B., Petronis, M.S., Stevenson, C.T.E., Clay, P.L. \& Gertisser, R. 2013. Magma Rheology Variations in Sheet Intrusions of the Ardnamurchan Central Complex (Scotland) Inferred from Gabbro Inclusion Characteristics. Journal of Petrology, 54, 75-102, http://doi.org/10.1093/petrology/egs064.

Magee, C., Muirhead, J., Schofield, N., Walker, R.J., Galland, O., Holford, S., Spacapan, J., Jackson, C.A., et al. $2019 \mathrm{~b}$. Structural signatures of igneous sheet intrusion propagation. Journal of Structural Geology, 125, 148-154.

Magee, C., Muirhead, J.D., Karvelas, A., Holford, S.P., Jackson, C.A., Bastow, I.D., Schofield, N., Stevenson, C.T., et al. 2016b. Lateral magma flow in mafic sill complexes. Geosphere, 12, 809-841.

Martin, S.A., Kavanagh, J.L., Biggin, A.J. \& Utley, J.E. 2019. The origin and evolution of magnetic fabrics in mafic sills. Frontiers in Earth Science, 7, 64.

O'Driscoll, B., Stevenson, C.T.E. \& Troll, V.R. 2008. Mineral Lamination Development in Layered Gabbros of the British Palaeogene Igneous Province: A Combined Anisotropy of Magnetic Susceptibility, Quantitative Textural and Mineral Chemistry Study. Journal of Petrology, 49, 1187-1221, http://doi.org/10.1093/petrology/egn022. 
O'Driscoll, B., Troll, V.R., Reavy, R.J. \& Turner, P. 2006. The Great Eucrite intrusion of Ardnamurchan, Scotland: Reevaluating the ring-dike concept. Geology, 34, 189, http://doi.org/10.1130/g22294.1.

Philpotts, A.R. \& Philpotts, D.E. 2007. Upward and downward flow in a camptonite dike as recorded by deformed vesicles and the anisotropy of magnetic susceptibility (AMS). Journal of Volcanology and Geothermal Research, 161, 81-94, http://doi.org/10.1016/j.jvolgeores.2006.11.006.

Planke, S., Rasmussen, T., Rey, S.S. \& Myklebust, R. 2005. Seismic characteristics and distribution of volcanic intrusions and hydrothermal vent complexes in the Vøring and Møre basins. In: Doré, A.G. (ed) Petroleum Geology: North-West Europe and Global Perspectives - Proceddings of the 6th Petroleum Geology Conference. Geological Society, London, 833-844.

Preston, R.J., Bell, B.R. \& Rogers, G. 1998. The Loch Scridain xenolithic sill complex, Isle of Mull, Scotland: fractional crystallization, assimilation, magma-mixing and crustal anatexis in subvolcanic conduits. Journal of Petrology, 39, 519-550.

Richey, J.E. \& Thomas, H.H. 1930. The Geology of Ardnamurchan, North-West Mull and Coll: A Description of Sheet 51 and Part of Sheet 52 of the Geological Map. Printed under the authority of HM Stationery Office.

Schofield, N. 2009. Linking sill morphology to emplacement mechanisms. University of Birmingham.

Schofield, N., Holford, S., Millett, J., Brown, D., Jolley, D., Passey, S.R., Muirhead, D., Grove, C., et al. 2017. Regional magma plumbing and emplacement mechanisms of the Faroe-Shetland Sill Complex: implications for magma transport and petroleum systems within sedimentary basins. Basin Research, 29, 41-63, http://doi.org/10.1111/bre.12164.

Schofield, N.J., Brown, D.J., Magee, C. \& Stevenson, C.T. 2012. Sill morphology and comparison of brittle and nonbrittle emplacement mechanisms. Journal of the Geological Society, 169, 127-141, http://doi.org/10.1144/0016$\underline{76492011-078 .}$

Sparks, R., Biggs, J. \& Neuberg, J. 2012. Monitoring volcanoes. Science, 335, 1310-1311, http://doi.org/10.1126/science.1219485.

Stephens, T., Walker, R., Healy, D., Bubeck, A., England, R. \& McCaffrey, K. 2017. Igneous sills record far-field and near-field stress interactions during volcano construction: Isle of Mull, Scotland. Earth and Planetary Science Letters, 478, 159-174.

Stevenson, C.T.E. \& Bennett, N. 2011. The emplacement of the Palaeogene Mourne Granite Centres, Northern Ireland: new results from the Western Mourne Centre. Journal of the Geological Society, 168, 831-836, http://doi.org/10.1144/0016-76492010-123.

Stevenson, C.T.E., Owens, W.H., Hutton, D.H.W., Hood, D.N. \& Meighan, I.G. 2007. Laccolithic, as opposed to cauldron subsidence, emplacement of the Eastern Mourne pluton, N. Ireland: evidence from anisotropy of magnetic susceptibility. Journal of the Geological Society, 164, 99-110, http://doi.org/10.1144/0016076492006-008. Igneous Province. Earth and Planetary Science Letters, 325-326, 1-9, http://doi.org/10.1016/i.epsl.2012.01.015. 
Tarling, D. \& Hrouda, F. 1993. Magnetic anisotropy of rocks. Springer.

Tauxe, L., Gee, J. \& Staudigel, H. 1998. Flow directions in dikes from anisotropy of magnetic susceptibility data: The bootstrap way. Journal of Geophysical Research: Solid Earth (1978-2012), 103, 17775-17790.

Thomson, K. \& Hutton, D. 2004. Geometry and growth of sill complexes: insights using 3D seismic from the North Rockall Trough. Bulletin of Volcanology, 66, 364-375, http://doi.org/10.1007/s00445-003-0320-z.

Thomson, K. \& Schofield, N. 2008. Lithological and structural controls on the emplacement and morphology of sills in sedimentary basins. In: Thomson, K. \& Petford, N. (eds) Structure and Emplacement of High-Level Magmatic Systems. Geological Society, London, Special Publications, 302, 31-44.

Tibaldi, A. 2015. Structure of volcano plumbing systems: A review of multi-parametric effects. Journal of Volcanology and Geothermal Research, 298, 85-135.

Wartho, J.A., Kelley, S.P. \& Blake, S. 2001. Magma flow regimes in sills deduced from Ar isotope systematics of host rocks. Journal of Geophysical Research: Solid Earth, 106, 4017-4035. 